\title{
Does the historical Jesus matter?
}

Marcus J Borg

Oregon State University

Visiting Professor: University of Pretoria

\begin{abstract}
Perceptions of the relationship between the historical study of Jesus and Christian theology have swung like a pendulum between two extremes. In the nineteenth century, there was a widespread assumption that the historical Jesus mattered significantly; for much of the twentieth century, the dominant claim has been that the historical Jesus has little or no theological significance. In recent scholarship, there are tentative steps toward affirming a 'both-and' position: though Christian faith is to some extent independent of historical research, it is also true that images of Jesus do very much affect images of the Christian life.
\end{abstract}

\section{INTRODUCTION}

The historical study of Jesus produces results very different from what Christians are accustomed to hearing and affirming about Jesus. Within Christian devotion, worship, and belief, Jesus is regularly spoken of as divine, indeed as the second person of the Trinity. The Nicene Creed, the great creed of the church formulated in the fourth century, speaks of him in the most exalted language:

We believe in one Lord, Jesus Christ,

the only Son of God,

eternally begotten of the Father,

God from God, Light from Light,

true God from true God,

begotten, not made,

of one Being with the Father.

Through him all things were made.

For us and for our salvation

he came down from heaven;

by the power of the Holy Spirit 
he became incarnate from the Virgin Mary, and was made man.

For our sake he was crucified under Pontius Pilate;

he suffered death and was buried.

On the third day he rose again

in accordance with the Scriptures;

he ascended into heaven

and is seated at the right hand of the Father.

He will come again to judge the living and the dead, and his kingdom will have no end ${ }^{1}$.

Yet historical scholarship about the pre-Easter Jesus affirms essentially none of this. We are quite certain that Jesus did not think of himself as divine or as 'Son of God' in any unique sense, if at all. If one of the disciples had responded to the question reportedly asked by Jesus in Mark's gospel, 'Who do people say that I am?', with words like those used in the Nicene Creed, we can well imagine that Jesus would have said, 'What???' Moreover, most Jesus scholars do not think Jesus was born of a virgin, or that he ascended into heaven in a visible way, or that there will be a literal second coming. Indeed, perhaps the only line from the Creed which would be seen as historical is the reference to his death: 'he was crucified under Pontius Pilate, suffered death, and was buried'.

Thus the quest for the historical Jesus often seems to call into question some of the most common and cherished Christian beliefs. Indeed, its foundational claim - that Jesus of Nazareth was quite different from how he is portrayed in the gospels and creeds of the church - can seem threatening to and destructive of Christian faith.

As one who is both a Christian and a Jesus scholar, I want to reflect on the relationship between Jesus scholarship and the Christian life. What is the significance of such scholarship for Christian theology, understanding, and life? Does the historical study of Jesus matter for Christians, and, if so, in what ways?

\section{A HISTORICAL PERSPECTIVE}

It is useful to see this issue as a sub-category of a larger question: what significance is to be given to the historical study of the Bible as it has emerged in the last few centuries of biblical scholarship? What happens to the claims of Christian theology, doctrine, dogma, and morals when the Bible is treated not as a divine product whose truth is guaranteed by its divine origin, but as a human product produced by two ancient cultures, namely ancient Israel and the early Christian movement? 
Until about three centuries ago, this was not an issue within the Christian world, anymore than it was an issue for Muslims to wonder whether the Koran came directly from Allah through the prophet Mohammed. No effort was required to believe this, for it was part of the taken-for-granted world of shared conviction. The gospels and the Bible as a whole were understood within the framework of 'natural literalism' or 'pre-critical naivete 3 . They were seen as divine documents whose truth was guaranteed by God. Therefore, the history which they reported was taken for granted actually to have happened.

This is not to say that every passage was understood literally. Theologians and Scripture scholars could find the 'spiritual' or 'allegorical' meaning of a text to be more important than the literal meaning, and could deny the literal meaning of some texts ${ }^{4}$. Nevertheless, if the text looked like it described something that happened or was said, it was taken-for-granted that what it reported was historically true: Adam and Eve in the Garden of Eden, Noah and the flood, God speaking to Moses through a burning bush, the walls of Jericho falling down in the time of Joshua, the miraculous deliverance of Daniel from the lions' den, the virgin birth with shepherds and wisemen in attendance, the stories of Jesus walking on the water, and so forth.

Within this view of Scripture, what Jesus was like could be known simply by combining together all that the Bible said about him 5 . No distinction had yet been made between Jesus as a historical figure and the Jesus who meets us on the surface of the gospels, between the pre-Easter Jesus and the post-Easter Jesus. The Jesus of history and the canonical Christ were seen as identical, and this identification was not even an article of faith. It required neither 'belief' nor effort, but was as self-evident to our ancestors as the heliocentric solar system is to us.

It was this understanding of the Bible and the gospels that was initially undermined and ultimately overturned by modern biblical scholarship. Modern biblical scholarship was the child of two parents: the Protestant Reformation of the 16th century and the Enlightenment which began about a century later. The Reformation emphasized the authority of the Bible (in contrast to church tradition), and thus gave to its study an importance which it had not had for over a thousand years. The Reformation also saw the Bible translated into popular languages, thereby making it widely accessible.

The Enlightenment, with its emphasis upon reason and scientific ways of knowing, engendered a revolution in knowledge. No longer could something be accepted as 'true' simply on the basis of authority and tradition. Investigation and reason became the new basis for knowledge. Applied initially in the natural world of the sciences, the new way of knowing soon was applied in the human world of history and culture. Within the worldview of the Enlightenment, both sacred authority and supernatural causation were rejected, and instead the effort was made to understand everything within a natural system of cause and effect. 
In the sphere of religion and theology, the early bearers of the Enlightenment were the Deists. Like their counterparts in the sciences, they consistently sought 'reasonable' and 'natural' explanations. Though the Deists still affirmed the existence of God, they rejected the notions of supernatural intervention and special revelation. With these gone, the privileged status of the Bible and of Christian doctrine also vanished. Scripture and doctrine alike were seen as human products, not as the result of special divine revelation.

Accompanying this was the rise of a new historical consciousness. The task of the historian was no longer seen as simply chronicling events reported in authoritative documents. Rather, the historian now became the judge of historical documents, seeking to make discriminating judgments about their origin, character, and ultimately about 'what really happened'6.

Modern biblical scholarship was born in the areas where the Protestant Reformation and the Enlightenment were most influential: Germany, the Netherlands, the British isles, and to a lesser extent France. Most of the early work was done on the Old Testament. In Holland in 1644, Hugo Grotius argued that the Old Testament was to be understood in relation to its original historical circumstances, and not primarily in relationship to the New Testament. A third of a century later, the famous philosopher Benedict Spinoza argued that the author of the Pentateuch was not Moses, but Ezra (who lived about nine hundred years after Moses). In France in 1678, Richard Simon (a Catholic) argued that much of the Old Testament had been compiled by scribal schools rather than written by inspired individuals.

The initial impact of this new approach to the Bible was controversial, to put it mildly, and world-threatening, to put it more accurately. In 1697 an eighteen year old Scottish student named Thomas Aikenhead was hanged in Edinburgh for claiming (as Spinoza had some twenty years earlier) that Ezra (and not Moses) was the author of the Pentateuch. Some thirty years later in England, the fate of Thomas Woolston, a professor at Cambridge, was considerably milder: he was sentenced to a year's imprisonment for his claim that the miracles of Jesus did not happen. Near the end of the 1700s, Thomas Paine (of American Revolutionary War fame) in his Age of reason denied the truthfulness of both the Old and New Testaments. His publishers in England were heavily fined and sent to prison?

In that world biblical criticism was seen as a threat to society: it seemed to call into question the truth of Christianity and therefore the underpinnings of Western culture itself. What seemed to be at stake for many was the sacred foundation of a world. Thus it was taken for granted that historical claims regarding the origin of the Bible and of Christianity mattered a great deal. 


\subsection{Early period: The historical Jesus matters}

It was in this period that the quest for the historical Jesus began. Like the early forays in biblical criticism, it generated both controversy and conflict. Hermann Samuel Reimarus (1694-1768), a professor of Oriental languages in Hamburg, is usually credited with the honor of being its father ${ }^{8}$. The work for which he is famous - The aims of Jesus and his disciples (1778) - was published posthumously and anonymously by Gotthold Lessing, who used a ruse to get it past state censorship which forbade the publication of works injurious to religion. The identity of the author was not disclosed for almost fifty years because of fear of bringing harm to his family. In 1835, a two-volume 1400 page life of Jesus by David Friedrich Strauss (remarkably, only twenty-seven years old) was published. Among other things, Strauss argued that the miracle stories were to be understood as myth, not history. He lost his academic position in Tübingen and was in effect banned for life from a university career. One reviewer referred to his book as 'the Iscariotism of our day9'. To say the obvious, many people in this period thought that what one affirmed about the historical Jesus mattered a great deal. Civil authority still sometimes took a hand, and outrage among church officials was common.

Thus, throughout the nineteenth century, there was widespread agreement that the historical Jesus had great significance for Christian faith. About this, hostile debunkers, orthodox defenders, and liberal revisionists agreed. Debunkers delightedly assumed that Christianity could be discredited by showing what the 'real' Jesus was like. Orthodox defenders, with their vigorous insistence upon the historical accuracy of the gospel portraits of Jesus, implicitly affirmed that any significant discrepancy would be destructive of the truth of Christianity. Liberal revisionists argued that Christianity could be purified and reformed by rediscovering the Jesus of history behind the doctrinal encrustations of the tradition. But all agreed: the historical Jesus mattered.

\subsection{The pendulum swings}

Around the end of the nineteenth century, the claim that the historical Jesus matters changed. Indeed, it was turned on its head. Throughout much of the twentieth century, the dominant position has been that the historical Jesus (defined more precisely as the historian's Jesus, namely, as what the historian can affirm about Jesus) has little or no significance for Christian theology and faith.

The reversal was due largely to the work of two scholars, Martin Kähler (18351912) and Albert Schweitzer (1875-1965). In a book published in Germany in 1892 and translated into English as The so-called historical Jesus and the historic Biblical Christ ${ }^{11}$, Kähler, a professor of systematic theology, argued that the historical Jesus 
does not matter for Christian faith and theology; rather, only the biblical Christ does. For Kähler, the historical Jesus was the historically-reconstructed Jesus, the result of the historian's activity. The biblical Christ is the Christ of the gospels and the New Testament. The historical Jesus, he argued, cannot be decisively important for Christian faith, in part because the gospels do not provide adequate material to write a life of Jesus, and in part because all historical reconstructions are relative and can at most be probable, not certain. Christian faith cannot be faith in constantly changing historical reconstructions accessible only through the work of scholars. If it were, it would, among other things, make Christian faith inaccessible to most Christians. Rather, Kähler argued, Christian faith is faith in 'the biblical Christ,' the Christ of early Christian proclamation as found in the New Testament as a whole. It is the Christ of the church's proclamation - the kerygmatic Christ - who matters for faith and theology. The historical Jesus does not.

In different terms, a similar position was articulated by Albert Schweitzer in the epilogue to his epochal Quest for the historical Jesus (1906). In the conclusion of a book in which he (at age thirty) brilliantly systematized the history of the quest to his day and then argued for an eschatological understanding of Jesus which was to dominate scholarship throughout much of the twentieth century, he pronounced the whole enterprise theologically and religiously irrelevant. The Jesus discovered by historical research was, he wrote, 'a stranger to our time'. He was strange to a large extent because of the eschatological beliefs which, Schweitzer argued, animated his life: Jesus believed that the supernatural Kingdom of God was at hand, and that he himself would be transformed into the apocalyptic 'Son of man' who would rule that Kingdom as God's vice-regent and Messiah. And, of course, he was wrong ${ }^{11}$. But that doesn't matter, Schweitzer continued, for it is the spiritual Christ, not the historical Jesus, who matters for us who live in the centuries since. The spiritual Christ is the one who is still known; the historical Jesus is a remote and strange figure from the distant past. To paraphrase the moving paragraph with which Scwheitzer ended his epilogue: the spiritual Christ is a living reality who still comes to us as one unknown, as of old, by the lakeshore, he came to those who knew him not. The spiritual Christ speaks to us the same words: 'Follow thou me'. And in relationship to that Christ (not to the historical Jesus), we come to know him as he is.

The impact of Kähler and Schweitzer extended long into the twentieth century. The claim that the historical Jesus is irrelevant to Christian theology and faith became the dominant position among both theologians and Jesus scholars. In a famous formulation, Rudolf Bultmann (1884-1976) argued that only the 'thatness' of Jesus mattered, not the 'whatness'. That is, only that Jesus existed and was crucified matters, not the what of his historical life ${ }^{12}$. 
For both theologians and Jesus scholars, the position had an attractive feature. It created a 'truce' that enabled both to go about their work without needing to pay much attention to each other.

\subsection{The current scene}

In broad strokes this was the situation at mid-century. In retrospect, one can see that Jesus scholarship from its beginning up to this period saw a pendulum swing between the poles of two related either/or's. The first either/or was the historical Jesus or the Christ of faith (who may also be spoken of as the biblical Christ or kerygmatic Christ). Who is normative for Christian faith and theology? Is it the historical Jesus or the Christ of faith? The second either/or was a common (though not necessary) corollary of the first: either the historical Jesus is of normative importance, or he is of little or no significance at all. To speak schematically, scholarship in the nineteenth century generally affirmed the Jesus of history (and thus the theological importance of the historical study of Jesus), and in much of the twentieth century affirmed the Christ of faith (and hence the theological unimportance of historical Jesus scholarship). The present scene is marked both by a continuation of the mid-century position and movement beyond it.

The last few decades have seen an increasing separation between historical Jesus scholarship and systematic theology (including christology) as intellectual disciplines, and a corresponding separation of historical Jesus scholarship from an explicitly Christian theological agenda. The reasons are quite mundane. One is institutional: many Jesus scholars now teach in the increasingly secularized and pluralistic environment of colleges and universities, rather than seminaries. As a result, historical Jesus scholars are not routinely involved in scholarly dialogue with theologians, and the questions they treat are not often generated by explicitly theological concerns.

A second factor is the increasing specialization of the academy and the proliferation of publication within each discipline. To speak for myself, I simply do not have time to keep up with publications in my own discipline and also to read widely in contemporary theology and christology, especially since my teaching responsibilities (like most of us in small departments) require me to be relatively current in a number of subdisciplines of religious studies (in my case, as diverse as religion and psychology, environmental ethics, and religion and culture). And for the same reasons, most theologians (including those doing christology) are not involved in sustained dialogue with Jesus scholarship.

There is gain in the separation of Jesus scholarship from a theological agenda. It has generated fresh questions and emphases in historical Jesus scholarship (see Borg 1994). But it has also contributed to the persistence of the mid-century truce ${ }^{13}$. The 
basis of the truce - the sharp separation of historical Jesus research and the theological enterprise - continues to be affirmed in many quarters. My impression is that it is still the most common position: historical Jesus scholarship is thought by many scholars (especially by those outside of the discipline itself but in related disciplines such as New Testament and theology) to be not only historically difficult to the point of being problematic, but also without theological relevance. Yet the second half of the century has also seen significant movement away from the sharp 'either/or' of earlier scholarship to more of a 'both-and' position.

\subsubsection{The 'New Quest'}

That movement began with the 'new quest' or 'second quest' of the historical Jesus in the 1950's. It accepted the centrality of the kerygmatic Christ for faith and theology, even as it also rejected the sharp separation from the Jesus of history. Initiated in a lecture by Ernst Käsemann in 1953 and crystallized in James Robinson's 1959 book A new quest of the historical Jesus, the new quest was marked by two central claims regarding the importance of the historical Jesus (Käsemann 1964:15-47; Robinson 1983). Without a connection to Jesus of Nazareth, Christianity risks falling into docetism and/or an ahistorical piety. Moreover, the synoptic gospels themselves provide warrant for taking the historical Jesus seriously: by preserving traditions about Jesus even as they adapt them and create new ones, the evangelists suggest that the pastness of Jesus' life was significant for Christian life in their own present time. Thus the new quest affirmed a role for historical knowledge of Jesus, even though its actual focus ended up being quite narrow ${ }^{14}$.

\subsubsection{Norman Perrin}

In a work published in the late 1960's, Perrin (the most prominent Jesus scholar in North America at the time of his death in 1976) assigned considerable theological importance to the historical study of Jesus ${ }^{15}$. To see this, it is illuminating to begin with Perrin's useful notion of 'faith-image' of Jesus. Every Christian has such a 'faithimage,' which is the the product of everything the Christian has assimilated about Jesus, whether from listening to sermons, hearing the gospels, reciting creeds, or singing hymns ${ }^{16}$. Faith-images are ultimately the product of Christian proclamation (in a comprehensive sense), not directly the result of historical research. Thus for Perrin (in continuity with Kähler and Bultmann, both of whom he explicitly cites), the proclaimed Christ is granted primacy.

What then is the relationship between the historical study of Jesus and the proclaimed Christ found in the faith-images of Christians? Here Perrin moves significantly beyond Kähler. and Bultmann and assigns two roles to historical Jesus 
scholarship. First, it can contribute to the formation and revision of the faith-image by providing content. Christian faith, Perrin writes, is:

... necessarily faith in something, a believer believes in something, and in so far as that 'something' is 'Jesus', historical knowledge can help to provide the content, without thereby becoming the main source of that content.

(Perrin 1967:24417)

Second, Perrin affirms that historical knowledge about Jesus can be used as a basis for discriminating among the great variety of proclamations which claim to be Christian. In a situation in which everything from 'radical right racism to revolutionary Christian humanism' is proclaimed as Christian kerygma, historical knowledge about Jesus can be 'a means of testing the claims of the Christs presented in the competing kerygmata to be Jesus Christ'. This leads to a striking statement: The true kerygmatic Christ, the justifiable faith-image, is that consistent with the historical Jesus.

It is a strong statement. The historical study of Jesus is assigned no less a role than the validation or invalidation of a given version of Christian proclamation as really Christian ${ }^{18}$.

If we were to emphasize only this part of Perrin, it would seem as if we had gone back to the nineteenth century: the historical Jesus is normative for discerning what is authentically Christian. What makes Perrin's position not simply a return to the nineteenth century is, of course, his strong affirmation of the primacy of the kerygmatic Christ, the Christ of faith. Rather than being a return to one pole of the 'either/or' of earlier scholarship, Perrin (like the new quest) represents movement to a 'both/and' position.

The 'both/and' position affirms that the historical Jesus matters for Christians. Such is also affirmed in two very recent works by major Jesus scholars, John P Meier and John Dominic Crossan. Though there are central differences between the two, both agree that the historical study of Jesus has significance for Christian theology and life.

\subsubsection{John Meier}

Meier's position is sketched in a chapter entitled, 'Why bother? The relevance of the quest for the historical Jesus' (Meier 1991:196-20119). In continuity with the twentieth century's emphasis on the Christ of faith, Meier affirms that the historical Jesus is not the object of faith. The 'proper' and 'direct' object of Christian faith is the still living 
person Jesus Christ, 'who now lives, risen and glorified, forever in the Father's presence'. The object of faith 'cannot be an idea or scholarly reconstruction'. Given this, what use does historical scholarship about Jesus have for people of faith? Meier's answer: none - a negation which he immediately qualifies in an important way. Namely, it has no significance 'if one is asking solely about the direct object of Christian faith: Jesus Christ, crucified, risen, and presently reigning in his Church'. This Jesus - the living lord - 'is accessible to all believers, including all those who will never study history or theology for even a single day in their lives', as he was throughout the many centuries before the rise of historical scholarship (Meier 1991:198).

Yet though the historical Jesus is not significant for faith, Meier argues that he is significant for theology (defined as faith seeking understanding). Contemporary theology, Meier affirms, must appropriate the quest for the historical Jesus. He then lists four ways in which the study of the historical Jesus is significant. The first three include both a negation and affirmation, the fourth only a negation (see Meier 1991:199):

* It rules out reducing Christ to a cipher without content or to a mythic symbol by affirming that Christian faith is 'adherence to a particular person who said and did particular things in a particular time and place in human history';

* it rules out pious and docetic tendencies to ignore Jesus' humanity and to emphasize his divinity by reminding us that Jesus was a fully human first-century Jew living in Palestine;

* it rules out comfortable Christian domestications of Jesus by disclosing his nonconformist aspects, especially on religious issues ${ }^{20}$; and

* it rules out seeing Jesus as 'a this-worldly political revolutionary' and prevents Jesus from being claimed by any ideology.

Meier thus affirms a variation of the 'both/and' position: both the Christ of faith and the historical Jesus are significant for theology, even if only the former is significant for faith. Regarding how much of a role is assigned to the historical Jesus, much depends upon whether the negations in his list are emphasized, or whether negations and affirmations are given equal weight. If one emphasizes the negations, then the role of the historical Jesus for theology is largely formal: it precludes certain theological positions. It precludes seeing Christianity as an ahistorical myth, precludes docetism, and precludes using Jesus as legitimation for ideology. But if one equally emphasizes 
the affirmations, then positive content for theology can come from historical Jesus scholarship. The specific content of the message and activity of this 'particular person who said and did particular things in a particular time and place' would become theologically important. It is not clear to me how Meier himself would weight the emphases $^{21}$.

\subsubsection{John Dominic Crossan}

In his recent books, Crossan unambiguously affirms the importance of the historical Jesus. Christian faith, he emphasizes, is '(1) an act of faith (2) in the historical Jesus (3) as the manifestation of God' (see Crossan 1993:3-4; 1994:200). As such, Christian faith does not even presuppose Easter, but was present even before Easter whenever somebody saw in Jesus 'the manifestation of God 22 '.

Thus Christian faith, as Crossan defines it, preceded the kerygma. Negatively, Christian faith therefore cannot be defined primarily as faith in the kerygmatic Christ. Positively, because the historical Jesus is seen as the manifestation of God, it follows that what he was like and what he was up to is a disclosure of God.

Crossan grants that it is possible to have Christian faith without any reference to the historical Jesus, and then incisively adds, 'It is called Gnostic Christianity' (Crossan 1993:20).

But he argues that 'Catholic Christianity' is defined by its preservation of the dialectic between 'Jesus then' and 'Christ now' (Crossan 1991:423; 1994a:20-21, 159). Within this dialectic, historical reconstruction of Jesus is given a central place. Moreover, it is not to be devalued because it is historical reconstruction. Crossan (1991:424-426) emphasizes that such reconstruction is our only access to the past. He points out that the text of the Greek New Testament is a historical reconstruction, the product of a committee voting on variant readings. As Crossan puts it, 'If you cannot believe in something produced by reconstruction, you may have nothing left to believe in' (Crossan 1991:426).

Crossan does not spell out the implications for Christian faith and theology of his portrait of Jesus. His treatment of the question occurs as an epilogue to his work. But a few points are clear, it seems. To take the historical Jesus as 'a manifestation of God' implies that Jesus' vision of a radically egalitarian society is 'of God'. So also, at a high level of abstraction, Jesus' practice of free healing and his 'commissioning' of others as healers points to unmediated access to the sacred as central to his teaching and activity. Together, they challenge the social, political and religious hierarchies of his world and every world. Given what Crossan says, taking his reconstruction of Jesus seriously - that is, finding it, in broad outlines, to be plausible - should lead to sharing Jesus' egalitarian vision of an unbrokered kingdom. Moreover, Crossan clearly sees the Constantinian revolution (which was really counter-revolutionary) as a betrayal 
of the vision of Jesus and hence a betrayal of authentic Christianity. Thus, though Crossan may represent a strong form of the position, he is one with the tendency of post-new quest scholarship to ascribe theological importance to scholarship about the historical Jesus.

\section{MY OWN POSITION}

Thus the last few decades have seen affirmations that historical Jesus scholarship matters for Christian faith and life. In the last part of this chapter, I wish to describe how I presently see the issues myself. Two central claims seem important.

First, I agree in part with the position of Kähler and Schweitzer, though I think precision in formulating the agreement is very important. Namely, I agree with them that historical knowledge of Jesus is not essential to being a Christian. This seems selfevidently true; if it were not, then we would have to say that the vast majority of Christians throughout the centuries have not had authentic faith, for there was no possibility of historical knowledge of Jesus until the birth of the quest a couple of centuries ago.

Moreover, I do not think the truth of Christianity is at stake in the historical study of Jesus (or the Bible, for that matter). Its truth has at least a relative immunity to historical investigation. By this, I mean that Christianity seems obviously to be a viable religion. That may seem an odd way to talk about it. What I mean is that Christianity seems clearly to 'work': it is a means or vehicle by which people experience 'the sacred'. And I cannot imagine any historical discovery or claim causing it immediately to cease to 'work'. I say this not simply because religious beliefs tend to persist even in the face of contradictory data, but also because religious traditions can mediate the sacred independently of their historical or literal truth ${ }^{23}$.

Finally, in affirming that historical knowledge of Jesus is not essential for Christian faith, it is important to be precise about what one means by 'faith'. I am using 'faith' in a relatively narrow sense to refer to one's relationship to God, and Christian faith specifically is a trusting relationship to God as mediated by the Christian tradition. Faith in this sense - as one's relationship to God - is not dependent upon historical knowledge of Jesus.

If, however, one uses 'faith' in a broad sense so that it refers not only to one's relationship to God but becomes virtually a synonym for the whole of Christianity (as in the phrase 'the Christian faith'), then it seems obvious to me that historical knowledge of Jesus is relevant.

This leads to my second main claim: images of Jesus in fact very much affect images of the Christian life. Much of the scholarly debate about the significance of historical knowledge about Jesus for Christians has focussed on the question of whether 
it ought to be significant. Reasons for and against are then marshalled: to say 'yes' risks making authentic Christianity inaccessible to millions of Christians of the past and present, to say 'no' risks docetism, gnosticism, and other illnesses.

I prefer to begin in another place, namely with the descriptive statement that images of Jesus do in fact have a strong effect on the lives of Christians. Because of his central place in the Christian tradition, how we as Christians think of Jesus shapes our understanding of the Christian life itself.

Let me illustrate this initially by speaking of the 'popular image' of Jesus and how it affects one's image of the Christian life. By the popular image, I mean the widespread image of Jesus which most of us received as children, whether we grew up within the church or only on its fringes. It is an image of Jesus as the divine savior. Its answers to the classic questions of Jesus' identity, mission, and message are clear: Jesus was the divinely begotten Son of God, whose mission was to die for the sins of the world, and whose message was about himself, the saving purpose of his death, and the importance of believing in him. This image of Jesus leads to an understanding of the Christian life as consisting primarily of believing, whatever else it may also lead to. It creates what we might call a fideistic image of the Christian life, one whose essential quality is believing that Jesus is one's savior. The point: the image of Jesus shapes the image of the Christian life.

A second image of Jesus is not as widespread as the first but still fairly common: not Jesus as savior, but Jesus as teacher. Generally a de-dogmatized image of Jesus, it is what most commonly results when persons are no longer certain about the doctrinal features of the popular image. What remains is Jesus as a teacher of ethics or morals, and it leads to a moralistic understanding of the Christian life, often expressed in quite banal terms. The Christian life consists of 'being good' or of following 'the golden rule'.

To illustrate the point with one more comprehensive image of Jesus: the construal of Jesus as an eschatological prophet, which dominated much of this century's scholarship, had two different consequences. For some, it meant that there was no satisfying image of the historical Jesus, and it led to a strange silence about Jesus in parts of the mainstream church. Alternatively, in the hermeneutic which developed out of this image, it led to an existentialist understanding of the Christian life, which in most forms generated a highly individualized and internalized understanding of the message of Jesus.

The same relationship between how Christians think of Jesus and how Christians think of the Christian life is found if we move from global images of Jesus to more particular claims about him. To cite a few examples: if a Christian becomes persuaded that Jesus taught a subversive wisdom, it affects how that person sees the conventional wisdom of his or her own day; if a Christian becomes persuaded that Jesus countered 
the purity system of his day, it affects how she or he sees purity systems in our day; if a Christian become persuaded that Jesus indicted the ruling elites of his day, it affects how domination systems are seen in the present. Note that I am not saying that these perceptions ought to have an effect, but that they do. I have seen this happen again and again: a significant change in a Christian's perception of Jesus in fact affects that person's perception of the Christian life 24 .

My point is the correlation between images of Jesus and images of the Christian life. Given this correlation, the question is not so much whether images of Jesus ought to have theological significance. Rather, they do have theological significance at the very practical immediate level of Christian understanding, devotion, and piety. Our choice is to let that significance be largely unrecognized, unconscious, and unchallenged, or to be conscious and intentional about the relationship. In short, because historical scholarship about Jesus affects our image of Jesus and thus our image of the Christian life, it matters 25 .

\section{CONCLUDING SUGGESTIONS}

First, I would like to suggest a terminological shift that could affect our thinking and conversation about this subject. Namely, I would like to replace the phrases 'the Jesus of history' and 'the Christ of faith' with 'the pre-Easter Jesus' and 'the post-Easter Jesus'. By the pre-Easter Jesus, I mean of course the historical Jesus; by 'the postEaster Jesus,' I mean the Jesus of Christian experience and tradition in the years and centuries after the death of the pre-Easter Jesus.

For two reasons, I have never much cared for the phrase 'the Christ of faith'. It suggests a rather 'iffy' or hypothetical reality which can only be believed in, as contrasted to the 'real' Jesus of history. On the other hand, the phrase 'the post-Easter Jesus,' understood as the Jesus of Christian experience and tradition, makes it clear that 'the post-Easter Jesus' is an element of experience and not simply of 'faith'.

Furthermore, the language 'Christ of faith' tends to give 'the Christ of faith' a privileged position. That is, because the language itself suggests that 'the Christ of faith' is to be believed in rather than subjected to historical inquiry, it suggests that the Christ of faith is immune to the relative and changing character of historical scholarship. But we in fact know 'the Christ of faith' of early Christian experience and tradition (the biblical Christ) only through the same processes of historical investigation and reconstruction as are involved in the study of the pre-Easter Jesus. To explain: if one says that the biblical Christ is primary, one still needs to ask, 'Whose biblical Christ?' Matthew's, Mark's, Luke's, Paul's, John's? And which scholar's interpretation of Matthew's, Mark's, Luke's, Paul's, John's biblical Christ? Or if a composite, whose version of the composite? The notion that the historical Jesus involves historical reconstruction and the biblical Christ does not is simply wrong ${ }^{26}$. 
Second, it seems clear to me that we should not see our question as a sharp either/or between the pre-Easter Jesus and the post-Easter Jesus. Rather, it is more appropriate (though not as simple) to see it as a both/and, as a dialogical and dialectical relationship of the two rather than as a binary choice between opposites. My claim is that theology should deal with both the pre-Easter and post-Easter Jesus. Moreover, it seems inappropriate to talk about the norm for christology, as if there were only one. Rather than speaking about the norm, it is more helpful to speak about a plurality of data which theology needs to take into account.

Third, historical scholarship about Jesus helps to keep 'the dangerous and subversive memory of Jesus' alive ${ }^{27}$. The tendency of dogma and doctrine (and to a lesser extent, of theology itself) is to categorize and domesticate. Historical scholarship about the pre-Easter Jesus - like the historical study of doctrine itself - guards against the tendency of doctrinal formulations to become ideology. Throughout the centuries, it has been easy for Christian doctrine and theology to be co-opted by what Walter Wink calls 'the domination system'. Historical scholarship about Jesus can help to keep alive the liberating memory of Jesus as one who provocatively and courageously protested against systems of domestication and domination, who pointed beyond himself to the sacred mystery in which we live and move and have our being, and who brought into existence an alternative community with an alternative and egalitarian vision of human life in history.

Finally, it seems to me that the Christian doctrine of incarnation implies that the historical Jesus is important. The claim goes back to the New Testament itself: Jesus was God's Word - God's disclosure - become flesh. I do not presume to know what this might mean comprehensively, and it is important to guard against interpretations which verge on docetism ('Jesus was really God') or which restrict God's disclosure exclusively to Jesus, as if he were God's only revelation. But minimally, it seems to mean this: from the point-of-view of his earliest followers and for Christians in the centuries since, Jesus was an epiphany or manifestation of God. The product of the historical study of Jesus - a historically reconstructed image of Jesus - is, of course, not itself that epiphany. But to the extent that it provides a glimpse of Jesus, it provides a glimpse of the epiphany of God which he was.

\footnotetext{
* This is essay is a reworked version of Chapter Nine, Jesus in contemporary scholarship, published by Trinity Press International, Valley Forge, Pennsylvania. HTS is granted permission to reprint this article.
} 


\section{End Notes \\ 1 From The Book of Common Prayer (1979:358). The wording is identical in the Lutheran Book of Worship (1978:84).}

2 And even the claim that he was buried in a tomb has been questioned. Crossan (1994b:123-158) argues that it was customary for the Romans to prohibit normal burial of victims of crucifixion as a final shaming and humiliation, and that Jesus' body may have been cast into a common grave or even devoured by dogs. To say, as I have suggested, that Jesus' death may be the only historical referent in the creed is not to deny the resurrection. It does, however, imply that the resurrection is not a historical event in the ordinary sense of the word; I do not think you could have 'caught' the risen Christ on a videocam, though I assume that the crucifixion was the kind of event that could have been photographed.

3 For 'natural literalism' and the distinction between it and conscious literalism, see Tillich (1957:51-53).

4 Two examples, whose source I do not remember but which are recalled from usually reliable memory. About the part of the temptation narrative in which Satan takes Jesus to a high mountain from which he shows him all the kingdoms of the earth, Origen (early third century) commented: there is no such mountain; obviously, something else must be meant. About the passage in Genesis 3 in which we are told that Adam and Eve heard the sound of God walking in the garden of Eden in the cool of the day, Luther commented: God never walked in any garden; they must have heard something else, perhaps the sound of the wind; nature, which had previously seemed benevolent, had now become a source of fear.

5 See the comment of Evans (1989:6): 'Prior to the critical period of biblical studies, canonicity was the only test for determining the authenticity of the sayings of Jesus. What was in the New Testament was authentic; what was not in the New Testament was suspect'.

${ }^{6}$ For this change and its effect on theology and Scripture, see especially Van Harvey (1966).

${ }^{7}$ For these episodes and others see Neil (1963:238-293). For other useful surveys of the history of biblical interpretation, see Rogerson (1992:424-433) and Jeanrond (1992:433-443). See also Grant \& Tracy (1984).

8 Ever since Albert Schweitzer's famous book, The quest for the historical Jesus (1906), it has been a scholarly convention to date the beginning of the quest to Reimarus' work. He did, however, have predecessors, as Wright (in Anchor Bible Dictionary III, 796-802) and Brown (1985:29-55), point out. 
${ }^{9}$ For the history of this period of Jesus scholarship, see the works by Schweitzer and Brown in previous footnote.

10 The English translation by Carl E Braaten is from the 1896 German edition.

11 It should be noted that Schweitzer did not argue (as Kähler and others have done) that we cannot know much about the historical Jesus. That was not the point of Schweitzer's history of the quest; rather, Schweitzer used it as a springboard for creating his own sketch of the historical Jesus, which he himself (and others) found quite persuasive. His point is that the historical Jesus is irrelevant to our time because of his 'strangeness,' not because he is unknowable.

12 Bultmann (1934) as a historian thought we could say quite a bit about the what of Jesus' historical life (especially his message). Nevertheless, as a theologian he affirmed its irrelevance.

13 The separation is not intrinsically an affirmation of theological irrelevance. It is possible to do historical Jesus scholarship without an explicitly theological agenda, and then to raise the question of theological significance. This is what I have sought to do myself, and Crossan (1993) affirms this procedure for his own work. Crossan (1994a:152) says that though he is 'absolutely aware of the theological implications of historical Jesus research,' he nevertheless does not think they drive his own process; consistent with this, he treats theological implications at the end of his historical reconstruction. To deny a theologiocal agenda is not to claim a positivistic objectivity for either myself or Crossan; we are both aware of the subjectivity of the historian, the relativity and particularity of all vantage points, and the fact that unconscious factors (including theological ones) may shape our perception. But it is to say that the generative questions addressed to the texts have not been posed by the doctrinal claims of Christian theology.

14 Its narrowness flowed out its concentration on the message of Jesus and its use of an existential hermeneutic. It became concerned to show the continuity between the message of Jesus and the kerygma of the early church, and found it in the understanding of existence which they shared: both proclaimed the end of an old world (the world of inauthentic existence) and the coming of a new world (the world of authentic existence lived in relation to God). This is an important insight, but if taken as 'the whole' (rather than as a part) of what Jesus was about, it radically internalizes and individualizes his meaning.

15 See Perrin (1967:207-248), still one of the best chapter-length treatments of the subject. Other works from the period which continue to be important include Harvey (1966) and Keck (1971). 
16 To quote Perrin:

[T] he Jesus of one's faith-image is a mixture of historical reminiscence, at a somewhat distant remove, and myth, legend and idealism'. The validity of a faith-image is not directly dependent upon historical knowledge of Jesus, but upon 'the fact that it grows out of religious experience and is capable of mediating religious experience'.

(Perrin 1967:243-244)

17 The 'main source', Perrin (1967:244) continues, 'will always be the proclamation of the Church, a proclamation rising out of a Christian experience of the risen Lord'.

18 In Perrin's (1967:244) own language: 'To this limited extent our historical knowledge of Jesus validates the Christian kerygma; it does not validate it as kerygma, but it validates it as Christian'. Though Perrin speaks of this as 'limited,' it is a broad claim. Why then call it 'limited'? I construe his use of it to mean: although the central claims of the kerygma are beyond validation (for example, Jesus lives and is lord), claims about what Christianity means for life are testable by appeal to the historical study of Jesus (Perrin 1967:244).

19 The book is is volume one of what will be a three-volume work on Jesus (in the book itself, Meier speaks of two volumes, but has since decided that a third volume will be needed).

20 I trust that the last phrase is fair to Meier's position. The examples he cites all have to do with 'religious' issues: Jesus' 'association with the religious and social 'lowlife', his critique of 'external religious practices' which 'strangle the inner spirit of religion', and 'opposition to certain religious authorities' (Meier 1991:199).

21 My impression is that he emphasizes the negations more than the affirmations, though he could develop his position either way. The ambiguity is seen in the sentence which follows his statement that the historical Jesus can provide content for Christian faith: 'While the quest cannot supply the essential content of faith, it can help theology give greater concrete depth and color to that content' (Meier 1991:199; italics added). Given this statement, can the quest provide new content? Or does it only add 'depth and color' (a deepening and perhaps 'toning') to content known on other grounds?

22 This is an important point for Crossan. Not only does it give primacy to the historical Jesus (rather than to the kerygma of cross-resurrection), but it fits his perception of early Jesus movements (such as the $\mathrm{Q}$ community and Thomas community) for whom Jesus' death and resurrection were not central (if significant at all). 
23 Perhaps, over a long period of time, an absolutely outrageous discovery (what could it be?) would weaken Christianity enough so that it would cease to 'work' for large numbers of people and cause it effectively to disappear. But my point is that the core validity of Christianity has to do with its ability to mediate the sacred, not with the historical accuracy of any particular claim.

24 I am not claiming that the change in perception leads immediately to a change in how one lives one's life. For most people, the process is gradual and slow. But a change in one's perception of Jesus is most often accompanied by a change in one's vision of the Christian life and what it calls one to.

25 In addition to these remarks, see Borg (1994), chapter eight, about how historical Jesus scholarship can help us to read the gospels more discerningly.

26 A point made forcefully by Keck (1971:25):

Historians of Jesus carry no heavier handicap than anyone else. Just as the theologian's God-talk has no fixed Archimedean point but reflects his own historicity without diminishing his intent to talk about God as accurately as possible, so the historian intends his reconstruction to be an accurate comprehension of Jesus, and both the theologian and the historian are open to self-correction by means of the critical method itself. We should no longer be intimidated by the theologian's taunt, 'But whose historical Jesus shall I interpret?' as if that made refusing to deal with any historically recovered Jesus legitimate! This sort of objection has been around long enough; it is time to send it packing.

27 A phrase cited by Tracy $(1981: 239,245$ note 24). I believe that he derived it from Johannes Metz and Hans Küng. Tracy, I should note, does not affirm the position with which I end, which I see as being quite close to Crossan. Tracy gives theological primacy to the apostolic witness to Jesus, and only a subordinate role to the historical study of Jesus.

\section{Works consulted}

Borg, M J 1994. Jesus in contemporary scholarship. Valley Forge: Trinity Press International.

Brown, C 1985. Jesus in European Protestant thought. Grand Rapids: Baker.

Bultmann, R 1934. Jesus and the word. New York: Scribner's.

Crossan, J D 1991. The historical Jesus: The life of a Mediterranean Jewish peasant. New York: Harper.

1994a. The historical Jesus in earliest Christianity, in Carlson, J \& Ludwig, $\mathrm{R}$ A (eds), Jesus and faith: A Conversation on the work of John Dominic Crossan, 121, 142-164. Maryknoll: Orbis Books. 
Crossan, J D 1994b. Jesus: A revolutionary biography. San Francisco: Harper.

Evans, C A 1989. Authenticity criteria in life of Jesus research. Christian Scholar's Review 19, 6-31.

Grant, R M \& Tracy, D 1984. A short history of the interpretation of the Bible. Philadelphia: Fortress Press.

Harvey, V A 1966. The historian and the believer. New York: Macmillan.

Jeanrond, W G 1992. Interpretation, History of, in Anchor Bible Dictionary 3, 433443.

Kähler, M 1964. The so-called historical Jesus and the historic Biblical Christ, translated by $\mathrm{C}$ E Braaten. Philadelphia: Fortress.

Käsemann, E 1964. The problem of the historical Jesus. London: SCM.

Keck, L 1971. A future for the historical Jesus. Nashville: Abingdon.

Lutheran Book of Worship 1978. Minneapolis: Augsburg.

Meier, J P. 1991. A marginal Jew: Rethinking the historical Jesus. Jew York: Doubleday.

Neil, W 1963. The criticism and theological use of the Bible, 1700-1950, in Greenslade, S L (ed), The Cambridge history of the Bible, Vol 3, 238-293. Cambridge: Cambridge University Press.

Perrin, N 1967. Rediscovering the teaching of Jesus. New York: Harper \& Row.

Robinson, J 1959. A new quest of the historical Jesus. London: SCM.

Rogerson, J W 1992. Interpretation, History of, in Anchor Bible Dictionary 3, 424433.

Schweitzer, A [1906] 1968. The quest for the historical Jesus: A critical stuay of its progress from Reimarus to Wrede, with a new introduction by J A Robinson and translated by W A Montgomery. New York: Macmillan.

The Book of Common Prayer 1979. New York: Oxford University Press.

Tillich, P 1957. Dynamics of faith. New York: Harper and Row.

Tracy, D 1981. The analogical imagination. New York: Crossroad.

Wright, N T 1992. Jesus, quest for the historical, in Anchor Bible Dictionary 3, 796802. 